\title{
TINGKAT PENGETAHUAN DAN KEPATUHAN TENTANG DIIT DIABETES MELLITUS PADA PASIEN DIABETES MELLITUS DI PUSKESMAS SIBELA KOTA SURAKARTA
}

\author{
Insiyah, Rini Tri Hastuti \\ Kementerian Kesehatan Politeknik Kesehatan Surakarta Jurusan Keperawatan
}

\begin{abstract}
Knowledge, Compliance, Diabetes Mellitus Diet. The purpose of this study was to identify knowledge and compliance to type 2 diabetes diet in diabetic patients in Sibela Public Health Centre Surakarta. Result of this research will be utilized for health education program for type 2 diabetic patients in community. Sample of this research is type 2 diabetic patients by using purposive and snowball sampling. This research also includes health professional such as physician, nutritionist, and senior nurses for data triangulation. Instrumen in this research are net book, tape recorder and semi structure questionnaire to record the data from deep interview. The results show that there is various knowledge and compliance to diabetes diet in diabetic patients in Sibela Public Health Centre Surakarta. Patients have incomplete knowledge about diabetes mellitus. Patients are already well known about signs and symptoms, etiology, treatment, and diabetic complication but they are still uncertain with the number of energy needed and have no diet planning. Diet compliance is still low and patients consume more carbohydrate( $>65 \%)$ as source of energy. This lack of compliance can be influenced by the low of knowledge that can be resulted from the lack of information and the low of the level education and motivation. Refreshing of diabetes diet, family support and motivation from health professional through effective communication among health professional and family, monitoring nutritional status and appropriate diet is very important.
\end{abstract}

Keywords: Knowledge, Compliance, Diabetes Mellitus Diet

Abstrak : Tingkat Pengetahuan, Kepatuhan, Diit Diabetes Mellitus. Penelitian ini bertujuan untuk mengetahui tingkat pengetahuan dan kepatuhan tentang Diit DM pada pasien Diabetes Mellitus di Puskesmas Sibela Kota Surakarta dengan tujuan khusus untuk mengetahui karakteristik pasien Diabetes Mellitus, mendeskripsikan tingkat pengetahuan dan kepatuhan tentang diit DM pada pasien diabetes mellitus di Puskesmas Sibela Kota Surakarta. Data yang didapatkan dalam penelitian ini akan digunakan sebagai bahan dalam perencanaan pendidikan kesehatan khususnya bagi pasien diabetes mellitus di masyarakat. Sumber data dalam penelitian ini adalah kelompok pasien diabetes mellitus dengan metode pemilihan sample adalah secara purposive dan bersifat snowball sampling, petugas puskesmas, dan keluarga. Responden tenaga kesehatan diperoleh dari satu ahli gizi, satu dokter, satu perawat senior. Alat yang digunakan dalam penelitian ini adalah buku catatan, netbook untuk mencatat hasil wawancara, tape recorder untuk merekam semua percakapan/ pembicaraan. Instrumen dalam penelitian ini adalah pedoman wawancara semiterstruktur, alat perekam suara, catatan lapangan. Hasil penelitian menunjukkan bahwa tingkat pengetahuan dan kepatuhan tentang diit 
DM pada pasien Diabetes Mellitus di Puskesmas Sibela Kota Surakarta masih sangat beragam, pasien memiliki pengetahuan tentang diabetes mellitus yang tidak lengkap. Pasien telah mengenal tanda dan gejala, penyebab, penatalaksanaan, dan komplikasi tetapi tidak mengetahui jumlah diit dan tidak membuat perencanaan diit .Kepatuhan terhadap diit pasien juga masih rendah dengan sumber konsumsi makanan terbanyak dari karbohidrat > $65 \%$. Ketidakpatuhan bisa diakibatkan oleh keterbatasan pengetahuan akibat minimnya informasi dan keterbatasan pendidikan pasien dan masih rendahnya motivasi. Penyegaran kembali tentang diit DM, dukungan keluarga dan motivasi dari petugas kesehatan melalui komunikasi efektif petugas kesehatan, monitoring status gizi dan kebutuhan diit perlu dilakukan.

Kata Kunci: Tingkat Pengetahuan, Kepatuhan, DIIT Diabetes Mellitus

\section{PENDAHULUAN}

Tingginya prevalensi DM, yang sebagian besar adalah tergolong dalam DM tipe-2 disebabkan oleh interaksi antara faktor-faktor kerentanan genetis dan paparan terhadap lingkungan. Beberapa faktor lingkungan yang diperkirakan dapat meningkatkan faktor risiko DM tipe-2 adalah perubahan gaya hidup seseorang, diantaranya adalah kebiasaan makan yang tidak seimbang akan menyebabkan obesitas. Selain pola makan yang tidak seimbang, kurangnya aktifitas fisik juga merupakan faktor risiko dalam memicu terjadinya DM. Ketidak seimbangan pola makan dapat disebabkan oleh ketidakcukupan pengetahuan pasien atau ketidakpatuhan pasien terhadap diit. (Tjekyan, 2007; Awad dkk, 2013). Menurut (Trisnawati, 2013), peningkatan diabetes risiko diabetes seiring dengan umur, khususnya pada usia lebih dari 40 tahun, disebabkan karena pada usia tersebut mulai terjadi peningkatan intoleransi glukosa. Adanya proses penuaan menyebabkan berkurangnya kemampuan sel $\beta$ pankreas dalam memproduksi insulin. Selain itu pada individu yang berusia lebih tua terdapat penurunan aktivitas mitokondria di sel-sel otot sebesar $35 \%$. Hal ini berhubungan dengan peningkatan kadar lemak di otot sebesar $30 \%$ dan memicu terjadinya resistensi terhadap insulin. Penanganan yang baik terhadap penyakit ini sangat diperlukan dalam rangka mengurangi angka kesakitan dan kematian. Sebagian peningkatan jumlah penderita DM tipe 2 karena kurangnya pengetahuan tentang pengelolaan DM. Penderita DM yang mempunyai pengetahuan yang cukup tentang DM, kemudian selanjutnya mengubah perilakunya, akan dapat mengendalikan kondisi penyakitnya sehingga dapat hidup lebih lama. Inilah yang menyebabkan edukasi menjadi salah satu komponen penanganan DM (Witasari dkk, 2009). Latihan jasmani secara teratur dapat menurunkan kadar gula darah. Latihan jasmani selain untuk menjaga kebugaran juga dapat menurunkan berat badan, meningkatkan fungsi kardiovaskuler, dan memperbaiki semua aspek metabolik, termasuk memperbaiki sensitivitas insulin, sehingga akan memperbaiki kendali glukosa darah. Selain itu dengan latihan jasmani dapat meningkatkan fungsi respirasi, menurunkan LDL dan meningkatkan HDL sehingga sekaligus dapat mencegah penyakit jantung koroner apabila latihan jasmani ini dilakukan secara benar dan 
teratur (Utomo dkk, 2012; Awad dkk, 2013; Indriyani dkk, 2007).

DM tidak dapat disembuhkan, tetapi kadar gula darah dapat dikendalikan. Penderita DM sebaiknya melaksanakan 4 pilar pengelolaan DM yaitu edukasi, terapi gizi medis, latihan jasmani, dan intervensi farmakologis. Untuk dapat mencegah terjadinya komplikasi kronis, diperlukan pengendalian DM yang baik yang mempunyai sasaran dengan kriteria nilai baik, di antaranya gula darah puasa 80$100 \mathrm{mg} / \mathrm{dL}$, gula darah 2 jam sesudah makan 80-144 mg/dL, HbA1C <6,5\%, kolesterol total $<200 \mathrm{mg} / \mathrm{dL}$, trigliserida $<150 \mathrm{mg} / \mathrm{dL}$, IMT $18,5-22,9 \mathrm{~kg} / \mathrm{m} 2$ dan tekanan darah $<130 / 80 \mathrm{mmHg}$ (Mihardja, 2009; Utomo dkk, 2012).

Masalah penanggulangan diabetes mellitus salah satunya dipengaruhi oleh tingkat pengetahuan yang rendah. Menurut (Witasari dkk, 2009), tingkat pengetahuan yang rendah akan dapat mempengaruhi pola makan yang salah sehingga menyebabkan obesitas,yang akhirnya mengakibatkan kenaikan kadar glukosa darah. Salah satu upaya pencegahan DM adalah dengan perbaikan pola makan melalui pemilihan makanan yang tepat. Semakin rendah penyerapan karbohidrat, semakin rendah kadar glukosa darah. Kandungan serat yang tinggi dalam makanan akan mempunyai indeks glikemik yang rendah sehingga dapat memperpanjang pengosongan lambung yang dapat menurunkan sekresi insulin dan kadar kolesterol total dalam tubuh.

\section{METODE PENELITIAN}

Penelitian ini merupakan penelitian deskriptif qualitatif, yaitu mendeskripsikan tingkat pengetahuan dan kepatuhan tentang diit DM pada pasien diabetes mellitus di Puskesmas Sibela kota Surakarta dengan metode triangulasi teknik yaitu dengan observasi dan wawancara dan triangulasi sumber data dari pasien, petugas puskesmas, dan keluarga.

Metode pemilihan sample dalam penelitian ini adalah secara purposive dan bersifat snowball sampling, petugas puskesmas, dan keluarga. Responden tenaga kesehatan diperoleh dari satu ahli gizi, satu dokter, satu perawat senior. Jumlah total asupan energi perhari responden diperoleh melalui wawancara kemudian dikonversi dari ukuran rumah tangga (URT) ke dalam ukuan gram perhari dan dibandingkan dengan kecukupan energi individu yang dianjurkan perhari yang dihitung menggunakan rumus Brocca. Jadwal makan diperoleh melalui wawancara kemudian dibandingkan dengan standar Perkeni 2006. Alat yang digunakan dalam penelitian ini adalah buku catatan untuk mencatat semua percakapan dengan sumber data, netbook untuk mencatat hasil wawancara, tape recorder untuk merekam semua percakapan/ pembicaraan.

\section{HASIL PENELITIAN}

Semua responden berusia di atas 40 tahun sebanyak 30 responden( $100 \%$ ). Responden berjenis kelamin perempuan dan laki-laki memiliki proporsi yang sama masing-masing 15 responden (50\%). Mayoritas respendon sebagai karyawan swasta dan wiraswasta yaitu 14 responden( 47\%). Pendidikan SMA memiliki jumlah tertinggi yaitu 17 responden $(57 \%)$ dan hanya 2 responden saja $(7 \%)$ dari responden yang memiliki pendidikan sampai sarjana. Sebagian besar responden telah menderita penyakit 
DM Tipe 2 selama antara 2-7 tahun. Sedangkan pasien yang menderita DMT2 lebih dari 7 tahun sebanyak 11 responden (37\%), dan hanya ada 4 pasien baru DMT2 dengan lama menderita DMT2 kurang dari 2 tahun. Mayoritas responden memiliki status gizi normal yaitu sebanyak 23 responden $(77 \%)$ ada 7 responden memiliki status gizi lebih, dan tidak ada responden dengan status gizi kurang. Mayoritas responden mendefinisikan diabetes mellitus sebagai suatu penyakit karena gula darah meningkat atau lebih dari normal dan tidak bisa menyebutkan berapa angka gula darah normal. Hanya ada 1 responden yang menyatakan bahwa melalui pemeriksaan laboratorium gula darah sewaktu normal adalah $<200 \mathrm{mg} / \mathrm{dl}$. Seluruh pasien tidak mampu menjelaskan bahwa mereka menderita DMT2. Terdapat 1 responden yang mengatakan tidak tahu apakah pengertian dari penyakit yang dideritanya.

Beberapa tanda dan gejala diabetes mellitus yang diutarakan oleh responden antara lain: trias diabetes mellitus yang meliputi poli uria (banyak kencing), polidipsia (banyak minum), dan polifagia (banyak makan). Beberapa gejala dan tanda yang lain adalah responden menyatakan cepat lelah dan tubuh terasa lemas, kesemutan, luka sulit sembuh, sering pusing, mata rabun atau pandangan kabur, dan penurunan berat badan. Responden menyebutkan tanda dan gejala diabetes mellitus secara bervariasi. Sebanyak 20 responden menyampaikan bahwa mereka mengalami gejala umum diabetes mellitus yaitu poliuria, polidipsia, dan polifagia. Sembilan responden mengatakan bahwa mereka merasa cepat lelah dan lemas meskipun tidak melakukan pekerjaan yang berat.
Sebanyak 6 responden (20\%) mengalami kesemutan terutama pada kaki dan tangan dan ada lima responden menyatakan bahwa salah satu gejala diabetes yang dialami adalah luka sulit sembuh. Sebagian besar responden yaitu sebanyak 18 responden mengatakan bahwa diabetes dapat disebabkan karena keturunan dan pola makan yang tidak baik. Ada 3 responden yang menjawab bahwa penyebab diabetes mellitus adalah karena stress. Sebanyak 2 responden tidak tahu apa yang menyebabkan diabetes mellitus. Berdasarkan hasil wawancara dapat diambil ringkasan bahwa penatalaksanaan diabetes mellitus meliputi: pengaturan makan, cek gula darah, minum obat anti diabetik, suntik insulin, rajin kontrol ke puskesmas, melakukan olahraga secara teratur. Sebanyak 6 responden menyatakan bahwa dalam rangka mengatur makan mereka mengurangi konsumsi nasi. Delapan responden menyatakan bahwa olahraga sangat perlu sebagai pengelolaan diabetes mellitus. Tiga responden merasa wajib suntik insulin untuk mengatasi diabetes mellitusnya.

Beberapa hal yang diungkapkan oleh responden terkait dengan perencanaan diit adalah dengan mengurangi makan nasi, mengurangi minum manis, mengurangi jeroan, mengkonsumsi air putih sebanyak mungkin dan banyak makan sayur serta ada satu responden yang merasa perlu untuk mengatur jadwal makan. Terdapat 9 responden yang tidak merencanakan diitnya. Terkait dengan pengetahuan pasien tentang komplikasi diabetes mellitus, beberapa jawaban yang bisa dirangkum antara lain: merusak organ terutama ginjal, jantung, dan mata. 
Kepatuhan terhadap diit DM adalah bagaimana responden mengikuti aturan makan yang telah dianjurkan sesui dengan kebutuhan kalorinya yang harus dipenuhi dalam sehari. Kepatuhan tersebut meliputi: jumlah kalori, jenis makanan, dan jadwal makan. Kepatuhan terhadap diit DM ini didasarkan pada recall 24 jam. Sebanyak 15 responden telah memenuhi kecukupan energinya yaitu antara $90-119 \%$, ada 6 responden yang berada dalam kategori defisit tingkat rendah. Sebanyak 4 responden dikategorikan dalam defisit tingkat sedang dan 5 responden dalam kategori defisit tingkat tinggi dengan kecukupan energi $<70 \%$. Seluruh responden tidak mengetahui jumlah kalori yang harus dikonsumsi sehari-harinya. Dari wawancara dengan petugas kesehatan seperti dokter, ahli gizi dan perawat didapatkan data bahwa petugas gizi telah menginformasikan tentang kebutuhan diit pasien saat pertama kali didiagnosa diabetes mellitus dengan indikasi gula darah diatas normal. Penderita diabetes diberikan informasi gizi sekali saja karena adanya keterbatasan ketenagaan dimana petugas kesehatan juga memiliki tanggungjawab rangkap untuk kegiatan administratif. Sebagian besar responden mengkonsumsi nasi putih sebagai sumber makanannya. Sebagian kecil yang lainnya mengkonsumsi kentang, singkong, dan roti. Untuk lauk pauk yang paling sering dikonsumsi adalah telur, ayam, tahu, dan tempe. Dari segi kecukupan nutrisi yang bersumberkan karbohidrat, sebagian besar responden dikategorikan mengkonsumsi karbohidrat yang berlebih yaitu masingmasing mengkonsumsi karbohidrat lebih dari $65 \%$. Hanya ada 1 responden yang mengkonsumsi karbohidrat $65 \%$ dari seluruh energi yang dibutuhkan yang berarti dikategorikan normal. Rata-rata konsumsi karbohidrat adalah $80 \%$. Kebanyakan sumber karbohidrat yang dikonsumsi responden adalah nasi putih. Sebanyak 15 responden juga masih terbiasa minum teh manis dengan gula antara 1-2 sendok makan 3 kali sehari. Untuk makanan sumber protein telah dikonsumsi secara mencukupi (10-20\%) oleh sebanyak 10 responden. Sebanyak 20 responden masih kurang dalam mengkonsumsi protein yaitu kurang dari $15 \%$. Tidak ada responden yang berlebihan dalam mengkonsumsi protein sebagai bahan makanannya. Adapun konsumsi protein terendah adalah $10 \%$ dan tertinggi adalah mengkonsumsi $18 \%$ protein sebagai sumber makanannya. Rata-rata konsumsi protein adalah $14 \%$.

Sumber protein terbanyak yang dikonsumsi pasien adalah ikan, daging ayam dengan kulit, tahu, tempe dan sebagian kecil dari telur ayam, telur asin, susu sapi, dan daging sapi. Konsumsi lemak pada semua responden adalah kurang dari $20 \%$ sehingga dikategorikan kurang. Konsumsi lemak rata-rata pada responden penelitian ini adalah $7 \%$ dengan konsumsi terendah $4 \%$ dan tertinggi $10 \%$. Sumber lemak yang paling banyak dikonsumsi masih dalam bentuk digoreng seperti ikan, ayam, tahu dan tempe.

Responden dalam penelitian ini mayoritas telah mampu memenuhi kebutuhan seratnya secara mencukupi yaitu antara 20-35gr/hari, dan ada 6 responden yang konsumsi seratnya masih kurang dari $20 \mathrm{gr} / \mathrm{hr}$ yang artinya dikategorikan dalam kekurangan serat. Tidak ada responden dalam penelitian ini berlebihan dalam memenuhi kebutuhan seratnya. Sumber makanan yang dikonsumsi sebagai sumber serat antara 
lain sayur bayam, brokoli, buncis, buah melon, buah pepaya, dan sumber lauk dari kacang-kacangan terutama tempe. Berkaitan dengan jadwal makan 8 responden mengatakan makan 3 kali sehari makan utama, 1 responden mengatakan makan 2 kali sehari dan sebanyak 21 responden mengatakan tidak menerapkan jadwal makan. Sebagian besar responden cenderung makan ketika merasa lapar.

\section{PEMBAHASAN}

Pengetahuan pasien tentang pengertian penyakit DM adalah sebagian besar menyebutnya sebagai kenaikan gula darah yang tinggi namun tidak ada responden yang mampu menyebutkan secara lengkap tentang gula darah normal. Semua responden juga tidak mengetahui menderita DM tipe yang mana. Responden hanya tahu kalau gula darah mereka meningkat sehingga harus mengurangi konsumsi nasi dan gula. Selain pendidikan faktor kurang informasi tentang pengetahuan terkait diabetes mellitus juga menjadikan pengetahuan responden masih terbatas. Dalam penelitian ini responden hanya mendapatkan informasi sekali saja khususnya tentang diabetes mellitus pada saat responden pertama kali terdiagnosa, meskipun beberapa diantara juga mendapatkan informasi saat kegiatan senam Prolanis. Lamanya jarak waktu antara pemberian informasi tentang DM dengan lamanya menderita DM menyebabkan hilangnya memori tentang informasi yang diberikan. Tersedianya sumber informasi selain petugas kesehatan juga belum menjamin responden memperoleh informasi secara lengkap dan benar. Al-Qazaz, H.K., et al( 2011) dalam penelitiannya juga menemukan bahwa sebagian pasien menyadari bahwa dirinya menderita penyakit diabetes akan tetapi termasuk dalam kategori diabetes yang mana mereka tidak tahu. Hambatan finansial, kelupaan, pengobatan sendiri, kualitas hubungan dengan dokter dan keluarga menjadi faktor yang mempengaruhi kepatuhan terhadap aturan terkait dengan penatalaksanaan pasien diabetes. Pengetahuan responden tentang tanda dan gejala, mayoritas responden mampu menjelaskan gejala trias DM dan mengalaminya. Beberapa gejala lain antara lain: merasa cepat lelah dan lemas meskipun tidak melakukan pekerjaan yang berat, kesemutan terutama pada kaki dan tangan, adanya luka yang sulit sembuh, pandangan kabur, sering pusing dan mengalami penurunan berat badan juga telah dikenali oleh beberapa responden. Pengetah uan pasien tentang tanda dan gejala cukup baik karena pasien sering mengalami dan merasakannya dalam waktu yang cukup lama setelah mereka menderita DM.

Dalam penelitian ini mayoritas responden berupaya mematuhi kebutuhan makan. Namun demikian karena keterbatasan pengetahuan terutama terkait dengan banyaknya jumlah energi yang harus dikonsumsi sehari-hari maka menyebabkan jumlah kalori yang dikonsumsi tidak sesuai dan diperoleh dari sumber makanan arau jenis makanan secara tidak seimbang sesuai dengan aturan. Mayoritas pasien dalam penelitian ini adalah lansia sehingga selain menderita diabetes mereka juga harus memperhatikan diit terkait dengan penyakit yang sering muncul pada lansia. Dalam penelitian ini beberapa responden mengikuti kegiatan prolanis dimana salah satu kegiatannya antara lain tentang penyuluhan gizi. Seluruh pasien yang 
datang dalam program prolanis memiliki penyakit yang beragam antara lain hipertensi dan diabetes mellitus. Penyampaian informasi yang tidak secara khusus pada pasien dengan jenis penyakit yang sama dan faktor usia serta pendidikan dimungkinkan dapat mempengaruhi pemahaman terhadap informasi yang diberikan. Diit pada umumnya bagi pasien hipertensi adalah dengan mengurangi makanan salah satunya adalah lemak dan kolesterol dimungkinkan juga mempengaruhi asupan nutrisi pasien diabetes mellitus.

\section{KESIMPULAN DAN SARAN}

Pasien diabetes mellitus di Puskesmas Sibela Kota Surakarta sebagian besar telah mampu menjelaskan tentang pengertian diabetes mellitus meskipun tidak secara lengkap. Pasien telah mengenal tanda dan gejala diabetes mellitus tipe 2. Adapun sebagai faktor penyebab antara lain keturunan dan disebabkan oleh pola makan yang tidak benar, faktor stres dan kurangnya aktifitas olahraga. Penatalaksanaan diabetes mellitus yang dilakukan oleh pasien meliputi: pengaturan makan, cek gula darah, minum obat anti diabetik, suntik insulin, rajin kontrol ke puskesmas, dan melakukan olahraga secara teratur. Namun demikian pasien tidak mampu menyebutkan jumlah diit yang seharusnya dalam ukuran jumlah kalori yang dimaksudkan dan tidak membuat perencanaan diit dengan alasan masih bingung dan memiliki persepsi bahwa yang terpenting adalah mengurangi gula dan nasi. Sementara komplikasi diabetes mellitus telah diketahui secara baik oleh pasien.

Terkait dengan kepatuhan terhadap diit yang meliputi: jumlah kalori, jenis makanan, dan jadwal makan, pasien masih belum bisa mematuhi diit yang ada dimana hal ini terjadi karena pasien belum mampu menetapkan jumlah kalori yang harus dikonsumsi setiap harinya dan dari sumber yang lengkap. Ketidakpatuhan pasien terhadap diit diabetes mellitus dimungkinkan karena keterbatasan pengetahuan akibat minimnya informasi dan keterbatasan pendidikan pasien dan masih rendahnya motivasi. diabetes mellitus di puskesmas Sibela Kota Surakarta memerlukan penyegaran kembali tentang pengetahuan diit DM sehingga dengan pemahaman yang baik tentang diit maka akan mendorong kepatuhannya dalam mengikuti diit yang diberikan. Selain itu faktor dukungan keluarga dan motivasi dari petugas kesehatan melalui komunikasi dan interaksi antara petugas kesehatan seperti dokter, ahli gizi dan keluarga yang baik seperti melalui kegiatan rutin prolanis juga menjadi hal yang penting mengingat pasien sebagian besar lansia. Monitoring status gizi dan kebutuhan diit dalam ukuran yang telah diatur dan direncanakan dalam bentuk program aplikasi yang dimiliki puskesmas Sibela, perlu dilakukan bekerja sama antar petugas kesehatan, pasien dan keluarga serta sumber daya yang ada di masyarakat seperti kader posyandu.

\section{DAFTAR RUJUKAN}

Al-Qazaz, H.K., Hassali, M.A. , Shafie, A.A., Syed, Sulaiman, S.A., Sundram, S.(2011). Perception and knowledge of patients with type 2 diabetes in Malaysia about their disease and medication: a qualitative study. Res Social Adm Pharm,7(2):180-91. doi: 10.1016/j.sapharm.2010.04.005. 
diakses

dari

http://www.ncbi.nlm.nih.gov/pubm ed/21272545.

Awad N, Langi YA, Pandelaki K.(2013). Gambaran Faktor Resiko Pasien Diabetes Melitus Tipe II di Poliklinik Endokrin Bagian/SMF FK-Unsrat RSU Prof. Dr. R.D. Kandou Manado Periode Mei 2011-Oktober 2011. Jurnal eBiomedik (eBM). 2013;1(1):45-9.

Jansiraninatarajan. (2013). Diabetic compliance: A qualitative study from the patient's perspective in developing countries. IOSR Journal of Nursing and Health Science (IOSR-JNHS) e-ISSN: 2320-1959.p- ISSN: 2320-1940 Volume 1, Issue 4 (May - Jun. 2013), PP 29-38. Diakses dari http:// Www.iosrjournals.org www.iosrjournals.org 29.

PERKENI. (2006). Konsensus

Pengelolaan Dan Pencegahan Diabetes Melitus Tipe 2 Di Indonesia. Jakarta : Penerbit PERKENI

Utomo OM, Azam M, Anggraini DN.(2012). Pengaruh Senam Terhadap Kadar Gula Darah Penderita Diabetes. Unnes Journal of Public Health ,1(1):36-40.

Witasari U, Rahmawaty S, Zulaekah S.(2009). Hubungan Tingkat Pengetahuan, Asupan Karbohidrat dan Serat dengan Pengendalian Kadar Glukosa Darah pada Penderita Diabetes Melitus Tipe 2. Jurnal Penelitian Sains \& Teknologi,10(2):130-8. 